\title{
PREZENTACJE
}

Anna Maria Apanel

DOI: $10.14746 /$ BHW.2015.33.9

Piotr Kotarski

Wydział Lekarski

Gdański Uniwersytet Medyczny

\section{Wiktor Dega - wybitny lekarz i pedagog (1896-1995) - wspomnienie w dwudziestą rocznicę śmierci}

\begin{abstract}
Wiktor Dega - a remarkable medical doctor and educator (1896-1995) - reminiscences on the 20th anniversary of his death

This elaboration concerns reminiscences on a remarkable human being, medical doctor - an orthopaedist and educator - Wiktor Dega. It consists of two fundamental parts: a biographical part and the other showing the professor's role in treating and developing a medical care for a child with motor dysfunction.

It also presents Wiktor Dega's academic and didactic activity and his efforts in arranging the first free of charge courses in orthopaedic gymnastics in Poznan primary schools for children with poor posture. This activity was deeply rooted in the professor's interest in rehabilitation.

Wiktor Dega was a co-founder and the first president of the Polish Association for Combating Disability [Towarzystwo do Walki z Kalectwem]. He was a member of the Executive Board of the Polish Academy of Sciences, a member of the Scientific Council at the Ministry of Health and Social Care, an expert for rehabilitation at the WHO and one of advisers of the World Health Fund in New York. For many years he was also a national rehabilitation specialist, the president of the Polish Orthopaedic and Traumatology Association as well as chief editor of the magazine called "Chirurgia Narządów Ruchu i Ortopedii Polskiej”.
\end{abstract}

He was also an honorary citizen of Poznań.

Keywords: Wiktor Dega, lekarz, ortopeda, pedagog, wspomnienie

\section{Wprowadzenie - elementy biografii}

Wiktor Dega urodził się 7 grudnia 1896 r. w Poznaniu. Jego rodzicami byli: Wiktor Dega - wicedyrektor Zakładu Ubezpieczeń oraz Zofia z domu Korzbok-Tuchołka. 
Uczył się w Gimnazjum św. Marii Magdaleny, którego jednak nie ukończył z powodu wybuchu I wojny światowej. Podczas nauki w tej placówce należał do Towarzystwa Tomasza Zana. W 1915 r. został powołany do armii niemieckiej, w której służył do zakończenia wojny. Następnie wziął udział w powstaniu wielkopolskim, wsławiając się w walkach o lotnisko na Ławicy. W służbie czynnej w wojsku polskim pozostawał do 1920 r. W 1919 r., jeszcze podczas służby w armii niemieckiej zdał maturę w i rozpoczął studia na uniwersytecie w Berlinie.

Po opuszczeniu armii w 1920 r., rozpoczął studia na Uniwersytecie Warszawskim, a w 1922 r. przeniósł się na Wydział Lekarski Uniwersytetu Poznańskiego, gdzie w 1924 r. uzyskał tytuł doktora wszechnauk lekarskich ${ }^{1}$.

Specjalizację w zakresie chirurgii ortopedycznej rozpoczął jako asystent Kliniki Ortopedycznej Wydziału Lekarskiego, pod kierunkiem twórcy polskiej ortopedii, profesora Ireneusza Wierzejewskiego.

W latach 1931-1937 zajmował stanowisko prymariusza w Poznańskim Zakładzie Ortopedycznym im. B. S. Gąsiorowskiego. Tytuł doktora habilitowanego uzyskał w 1933 r. na podstawie rozprawy pt.: „Badania $z$ dziedziny etiologii i patogenezy wrodzonego zwichnięcia biodra". Opracowanie to, wówczas pionierskie, do dzisiaj cytowane jest w piśmiennictwie światowym jako jedno z klasycznych w ramach tego zagadnienia.

Do momentu wybuchu II wojny światowej W. Dega wykładał ortopedię i traumatologię na kierunku lekarskim Uniwersytetu Poznańskiego. W latach 1926-1937 pracował także jako asystent w Studium Wychowania Fizycznego Uniwersytetu Poznańskiego, przygotowując studentów do naukowego i praktycznego rozwiązywania zagadnień związanych ze stosowaniem gimnastyki leczniczej. W tym samym czasie zorganizował w szkołach powszechnych w Poznaniu pierwsze w Polsce bezpłatne kursy gimnastyki leczniczo-wyrównawczej dla dzieci z wadami postawy.

Od listopada 1937 r. do 31 sierpnia 1939 r. był ordynatorem zorganizowanego według własnych planów bardzo nowoczesnego Oddziału Ortopedycznego w Szpitalu Wojewódzkim w Bydgoszczy.

W. Dega doskonalił swoje wykształcenie również za granicą. W latach 1925-1926 pracował w Lyonie i w Paryżu, a w 1932 r. w Bolonii oraz w Sztokholmie. Zdobyte tam doświadczenia przenosił później na grunt polski.

W okresie II wojny światowej został zmobilizowany. Jako lekarz kapitan rezerwy armii polskiej brał udział w kampanii wrześniowej w ramach Armii Pomorze. W bitwie pod Kutnem został ranny. Po zwolnieniu z niewoli, w kwietniu 1940 r., objął stanowisko ordynatora Oddziału Chirurgii Dziecięcej w Szpitalu Karola i Marii w Warszawie. Podczas powstania warszawskiego pracował jako chirurg w szpitalu polowym w Lecznicy „Sano” przy ul. Lwowskiej. Po zakończeniu powstania, wraz ze Szpitalem Karola i Marii ewakuował się do Włodzimierzowa pod Piotrkowem Trybunalskim, gdzie pracował do zakończenia wojny.

${ }^{1}$ W. Dega, Zapiski do autobiografii. Moja droga życiowa do wiedzy i zawodu, w: Wiktor Dega - znany i nieznany, red. I. Stasiewicz-Jasiukowa, Poznań 2000, s. 59-115. 
W 1945 r. W. Dega wrócił do Poznania i objął kierownictwo Katedry i Kliniki Ortopedycznej Uniwersytetu Poznańskiego. Równocześnie uzyskał nominację na profesora nadzwyczajnego. Zorganizował od podstaw Klinikę Ortopedyczną z oddziałem rehabilitacji, warsztatami ortopedycznymi, pracownią psychologiczno-socjalną, szkołą podstawową, poradniami specjalistycznymi, pracowniami: anatomii, patofizjologii i biomechaniki oraz bazę materialną dla wszechstronnej działalności naukowej, leczniczej i dydaktycznej².

Po reformie w 1950 r., wraz z kierowaną przez siebie katedrą i kliniką przeszedł do nowo utworzonej Akademii Medycznej w Poznaniu. Zorganizowanie pracy kliniki od podstaw pozwoliło mu na wdrożenie własnego programu kompleksowego leczenia chorych z upośledzoną czynnością narządu ruchu. W 1956 r. został mianowany profesorem zwyczajnym. W latach 1959-1962 był rektorem AM w Poznaniu. W 1960 r. utworzył w Poznaniu pierwszą na świecie Katedrę Medycyny Rehabilitacyjnej. Jego sukcesy sprawiły, że w 1969 r. Ministerstwo Zdrowia włączyło rehabilitację w ramy organizacji opieki medycznej. W tym samym roku otrzymał doktorat Honoris Causa swojej uczelni. W następnym roku Europejskie Biuro WHO uznało za modelowy, opracowany przez W. Degę program kompleksowej rehabilitacji obecnej na każdym etapie leczenia.

Na dorobek naukowy W. Degi składa się ponad 250 prac, z czego około 60 dotyczy wrodzonych zwichnięć stawu biodrowego. Jego badania w tej dziedzinie stały się podstawą do opracowania metody operacyjnego leczenia nazywanej osteotomią transiliakalną.

Dnia 11 lutego 1992 r. uchwałą Rady Miasta Poznania otrzymał Honorowe Obywatelstwo Miasta Poznania ${ }^{3}$.

\section{Rola Profesora Wiktora Degi w rozwoju opieki na dzieckiem z dysfunkcją motoryczną}

Profesor nauk medycznych - lekarz chirurg i ortopeda - Wiktor Dega miał ogromne zasługi w rozwoju koncepcji opieki nad dzieckiem z dysfunkcją motoryczną.

W 1986 r. W. Dega wypowiedział słowa, którym wierny był przez całe dotychczasowe życie: Pierwsze spotkanie z kalectwem działa oczywiście destrukcyjnie, ale człowiek powinien być człowiekiem. Edukację człowieczeństwa trzeba zaczynać od dzieci. W przedszkolach $i$ szkołach angielskich siedza obok siebie $w$ tawkach dzieci zdrowe i kalekie, przyzwyczajaja się do siebie, pomagaja sobie nawzajem. My też dażymy do tego, ale ciagle nie możemy uwierzyć, że to ludzie zdrowi zobowiązani sa uczynić ludzkim świat ludzi niepetnosprawnych. [...] Obowiazkiem medycyny i lekarzy jest przede wszystkim dawanie chorym nadziei, wyrwanie ich z rozpaczy ${ }^{4}$.

\footnotetext{
2 Ibidem.

3 Ibidem.

${ }^{4}$ R. Poradowski, Wiktor Dega - w kręgu Mistrza - szkic do portretu, Łódź 2001, s. 6.
} 
Pierwsze lata powojenne, mimo trudnych warunków medycznych, społeczno-politycznych i ekonomicznych, sprzyjały rozwojowi idei rehabilitacji profesora W. Degi. W kraju było sporo osób z niepełnosprawnością motoryczną, szerzyła się gruźlica, choroby zbierały obfite żniwo. W 1950 r. wybuchła epidemia choroby Heinego-Medina. Ta tragedia stała się motorem postępu w rozwoju i zastosowaniu koncepcji W. Degi. Został mianowany przez ministra zdrowia, Krajowym Specjalistą do Spraw Rehabilitacji. W krótkim czasie chorobą tą dotkniętych zostało w Polsce ponad 6 tysięcy osób, głównie dzieci. W. Degę przerażały rozmiary tragedii i sam przebieg choroby. Z powodu braku szczepionki, lekarze mogli zalecać głównie intensywne ćwiczenia rehabilitacyjne. Profesor organizował więc szkolenia rehabilitantów, opracował metody rehabilitacji ludzi dotkniętych tą epidemią. W tym trudnym czasie W. Dega stosował także wiele metod operacyjnych zmierzających do usunięcia u dzieci deformacji stopy i jej stabilizacji bez naruszania elementów wzrostowych. Metody te przyniosły Profesorowi światową sławę. Ośrodek Poznański odwiedzany był przez światowe autorytety z dziedziny ortopedii i rehabilitacji. W 1957 r. W. Dega został ekspertem Światowej Organizacji Zdrowia z zakresu rehabilitacji i ten zaszczytny obowiązek pełnił aż do $1967 \mathrm{r}$.

W. Dega był gorącym zwolennikiem i niestrudzonym bojownikiem w walce o tworzenie w okresie Polski Ludowej szkolnych internatów ortopedycznych. Był to system domów pobytowych powiązanych ze szpitalem ortopedycznym, który pozwalał na usunięcie jednego z najważniejszych braków w leczeniu chorób przewlekłych u dzieci i młodzieży w wieku szkolnym. W „Projekcie organizacji lecznictwa ortopedycznego i opieki nad kalekami” W. Dega mówił: Jeśli np. dziecko siedmioletnie zachoruje na gruźlicę kręgostupa lub biodra, leczenie wymaga wielomiesięcznego, a nieraz kilkumiesięcznego unieruchomienia. Mało tylko rodziców może sobie pozwolić na zorganizowanie nauki szkolnej w domu. Większość dzieci takich jest przez kalectwo upośledzona nie tylko fizycznie, ale i pod względem wykształcenia. Gdy dziecko - po ukończeniu leczenia wkracza w życie, ma z obu przyczyn, tj. kalectwa i braku wyksztatcenia, dużo trudniejsze położenie aniżeli zdrowi rówieśnicy. Umieszczenie takich dzieci w internacie szkolnym, który jest zwiąany ze szpitalem i znajduje się $w$ mieście rodzinnym dzieci, rozwiązuje zagadnienie zupetnie wystarczająco. Dziecko pozostaje w leczeniu statym, nie traci kontaktu z rodzicami i otrzymuje potrzebna naukę. [...] W internacie takim można z tatwościa, dzięki wspótpracy szpitala i jego specjalistycznej opiece lekarskiej zastosować indywidualne podejście do fizycznych ułomności dzieci [...]. Internat szkolny stoi pod opieka kuratorium szkolnego, które organizuje nauczanie dzieci"'5.

W. Dega angażował władze oświatowe do zakładania takich placówek, ponieważ w ten sposób duży procent uczniów z niepełnosprawnością ruchową, równocześnie z nauką szkolną nabywało pewne umiejętności, które mogły stać się podstawą do późniejszego zawodu.

W 1966 r. podczas X Kongresu Międzynarodowego Towarzystwa Rehabilitacji Inwalidów w uznaniu zasług w rozwój światowej rehabilitacji otrzymał najwyższe odznacze-

${ }^{5}$ W. Dega, Projekt organizacji lecznictwa ortopedycznego i opieki nad kalekami, Warszawa 1948, s. $13-14$. 
nie - nagrodę im. A. Laskera. Profesor Howard A. Rusk, przewodniczący Komitetu Fundacji Alberta Laskera podczas Kongresu w Wiesbaden powiedział: Profesor Dega w swej działalności przekroczyt granice narodowe i stużyt swoja wiedza i praca całej ludzkości. Dzięki swemu zaangażowaniu i niesieniu pomocy bliźnim, dzięki szacunkowi i miłości, jakie sobie zdobyt wśród swoich wspótpracowników - profesor W. Dega jest dziś natchnieniem $i$ wzorem dla wszystkich działajacych na polu rehabilitacji ${ }^{6}$.

Był pierwszym pracownikiem służby zdrowia w naszym kraju uhonorowanym medalem Komisji Edukacji Narodowej. Szczególnym sentymentem darzył jednak inne niezwykle odznaczenie - Order Uśmiechu. Kawalerem tego orderu został dzięki dzieciom - najmłodszym pacjentom, którym niósł zawsze nadzieję i pomoc. Przez cały czas aktywnie działał jako współzałożyciel, a później prezes w Polskim Towarzystwie do Walki z Kalectwem. Celem tej organizacji było tworzenie i prowadzenie różnych form walki z kalectwem i inwalidztwem zarówno dorosłych, jak i dzieci oraz współpraca w tym zakresie z zainteresowanymi organizacjami społecznymi i naukowymi, resortowymi, instytucjami i radami narodowymi. W. Dega jako wieloletni prezes Towarzystwa położył olbrzymie zasługi dla rozwoju nowoczesnej rehabilitacji w naszym kraju.

Początki zainteresowań rehabilitacją sięgają połowy lat 20. XX w. Szczególnie interesowała go koncepcja słynnej szwedzkiej gimnastyki Pehr Henrika Linga, prekursora nowoczesnej rehabilitacji. Profesor zapoznał się z nią u źródeł, tj. podczas pobytu w Sztokholmie w klinice słynnego profesora Patryka Haglunda, gdzie skończył również kurs masażu. Największe wrażenie robił na nim jednak system opieki nad niepełnosprawnymi. Szwedzi już wówczas znakomicie łączyli leczenie z przystosowaniem pacjentów do samodzielnego życia.

Po powrocie do Polski wprowadził w poznańskich szkołach - pierwszy w kraju, gimnastykę korekcyjną dla dzieci z wadami postawy. Pomagała mu przy tym jego żona i kilka przeszkolonych nauczycielek. Jednak, gdy w 1937 r. przeniósł się do Bydgoszczy, nie znalazł nikogo, kto zgodziłby się przejąć jego obowiązki.

W. Dega w licznych swych wystąpieniach ${ }^{7}$ poruszał problem rehabilitacji środowiskowej, której zadaniem jest upowszechnienie rehabilitacji i zbliżenie jej do osoby niepełnosprawnej. Realizacja rehabilitacji środowiskowej wykracza daleko poza zasięg działania stużby zdrowia. Musi się w nia właczyć cała ludność środowiska, a więc administratorzy budynków, architekci, rodziny, placówki oświatowe, komunikacja, handel. itd. [...] Lekarz myślacy kategoriami rehabilitacji, nie może się ograniczyć do leczenia chorego narzadu, lecz musi leczyć chorego człowieka, jako członka społeczeństwa. Rehabilitacja przeciwstawia się dehumanizacji medycznej, w której postęp techniczny oddalit chorego od lekarza ${ }^{8}$.

W 1970 r. W. Dega przedstawił na posiedzeniu Biura Europejskiego Światowej Organizacji Zdrowia polską koncepcję kompleksowej rehabilitacji. Przyjęta została ona jako modelowa. W. Dega przekonywał, że sukces rehabilitacji medycznej musi wiązać się

\footnotetext{
${ }^{6}$ R. Poradowski, op. cit., s. 34.

7 Np.: II Kongres Polskiego Towarzystwa Walki z Kalectwem w 1983 roku.

${ }^{8}$ R. Poradowski, op. cit., s. 38.
} 
z podjęciem pracy przez pacjenta. Zaś rolą lekarzy jest stworzenie pacjentowi takich warunków, by stało się to realne. Profesor zwrócił uwagę na rolę instytucji i organizacji w procesie rehabilitacji niepełnosprawnych. W analizowanym okresie sojusznikiem rehabilitacji była spółdzielczość inwalidzka.

Wiele miejsca W. Dega poświęcił organizacji opieki społecznej nad dziećmi z niepełnosprawnością motoryczną oraz nauce szkolnej tych dzieci. Mówił, że należy odróżnić dwa rodzaje opieki społecznej. Opiekę, która była wówczas względnie dobrze rozwinięta, a która polegała na świadczeniach społecznych, zapomogach i pomocach zapewnionych przez ustawy. Drugi zaś rodzaj opieki socjalnej był ściśle związany z samą procedurą rehabilitacyjną i był wykonywany przez asystenta socjalnego. Stanowił on niejako łącznik między lekarzem a zespołem, który prowadzi rehabilitację i środowiskiem, w którym przebywa dziecko niepełnosprawne. Uważał, że rozeznanie w środowisku, w którym wzrasta dziecko niepełnosprawne jest bardzo istotne dla ustalenia samego programu rehabilitacji i dla sposobu jego realizacji. Według W. Degi opiekun społeczny winien wchodzić w skład każdej jednostki otwartego i zamkniętego lecznictwa rehabilitacyjnego. Brak opiekunów społecznych w Polsce odczuwało się jako dużą lukę w organizacji rehabilitacji, która wypełniana była przez doraźne dokształcanie personelu.

W odniesieniu do nauki szkolnej dzieci z niepełnosprawnością motoryczną mówił, że: Im dziecko kalekie jest bardziej umysłowo rozwinięte, tym bardziej efektywna jest jego rehabilitacja i tym łatwiejsze jest jego wtaczenie się w życie społeczne i zawodowe. Jako zasadę należy przyjąć, że dziecko kalekie winno możliwie uczęszczać do normalnej szkoty $i$ uczyć się wspólżycia ze zdrowymi dziećmi ${ }^{9}$.

W analizowanym okresie wiele ośrodków medycznych w kraju postulowało wprowadzenie zmian w kształceniu dzieci z niepełnosprawnością ruchową. W ośrodku gdańskim ${ }^{10}$ wyróżniano m.in. przeznaczenie pewnej liczby godzin na zajęcia dla nauczycieli celem prowadzenia nauki w domu lub tworzenie świetlic, gdzie można byłoby te dzieci dowozić i gdzie byłoby prowadzone systematyczne nauczanie. Jednak najkorzystniejszym wariantem, z uwagi na kontakt z dziećmi zdrowymi było uzyskanie pomieszczeń na terenie szkoły podstawowej. W tych warunkach odpadała opłata za pomieszczenie, była możliwość korzystania z pomocy szkolnych oraz co najważniejsze angażowano grono pedagogiczne w problem funkcjonowania edukacyjnego dzieci niepełnosprawnych, a u dzieci zdrowych wyrabiano właściwe podejście do niepełnosprawnych kolegów. Dzieci niepełnosprawne uczyły się współżycia ze zdrowymi kolegami, z którymi będą musiały współpracować, gdy dorosną.

W kwestii objęcia opieką edukacyjną, medyczną, socjalną niepełnosprawnych ruchowo dzieci wiejskich proponowano ( również W. Dega) rozbudowę sieci szkół podstawo-

\footnotetext{
9 W. Dega, Kierunki rozwoju organizacji rehabilitacji dziecka z kalectwem narzadu ruchu, w: Organizacja opieki nad dzieckiem kalekim jako zagadnienie stużby zdrowia. Materiały z Sympozjum, red. W. Dega, Poznań 1966, s. 17.

${ }_{10}$ Program ten zaprezentowały na Sympozjum w 1966 r. w Poznaniu: prof. dr med. Zofia Majewska z Kliniki Neurologicznej AM w Gdańsku oraz dr med. Zofia Anisimowicz z Sanatorium Rehabilitacyjnego dla Dzieci w Gdańsku, zob. Organizacja opieki nad dzieckiem kalekim jako zagadnienie stużby zdrowia. Materiaty z Sympozjum, red. W. Dega, Poznań 1966, s. 96-97.
} 
wych z internatami, gdzie dzieci z niepełnosprawnością ruchową byłyby umieszczane. Dzieci kalekie z racji swego kalectwa sa w dużm stopni wyobcowane ze społeczeństwa. Nie biora udziału w codziennych rozrywkach, spacerach, współżyciu z dziećmi. Dlatego szkoła skupiajaca większa gromadkę dzieci, poza zasadnicza rola, jaka jest zdobycie wie$d z y$ w zakresie szkoły podstawowej, odgrywa kolosalna role $w$ ksztaltowaniu świadomości spotecznej ${ }^{11}$.

Pracownicy kierowanej przez W. Degę Katedry i Kliniki Medycyny Rehabilitacyjnej uznawali znacznie kolonii letnich dla dzieci z niepełnosprawnością ruchową w procesie rehabilitacji medycznej i społecznej oraz w procesie integracji z dziećmi zdrowymi. Wspólnie z Kuratorium Okręgu Szkolnego Poznańskiego zorganizowano je dwukrotnie: w Mielnie koło Gniezna w 1964 r. oraz w Bninie koło Kórnika w 1965 r. Celem kolonii obok wypoczynku było dalsze usprawnianie lecznicze i psychiczne. Poza tym kolonie były sprawdzianem zdobytej przez dzieci sprawności i umiejętności wykorzystywania jej w warunkach „na co dzień”. W programie uwzględniano zajęcia z wychowania fizycznego w zakresie różnorodnych dyscyplin sportowych. Wymagano i przestrzegano, aby dzieci niepełnosprawne we właściwy sposób posługiwały się sprzętem ortopedycznym, aby samodzielnie wykonywały czynności życia codziennego. Wyrabiano nawyki związane z higieną osobistą. Organizowano wycieczki turystyczne. Wszelkim zajęciom nadawano formy zbliżone do wymogów dla dzieci zdrowych, stwarzano przeszkody możliwe do pokonania, prowadzono intensywną rehabilitację psychiczną. Ponieważ w kolonii uczestniczyły również dzieci zdrowe, była to dokładnie przemyślana koncepcja włączania dzieci niepełnosprawnych w tryb życia i wypoczynku dzieci zdrowych. Odpowiednio przemyślany i dostosowany regulamin dnia codziennego wytwarzał w dzieciach nawyki wychowawcze, które później mogły przenosić do swego środowiska domowego ${ }^{12}$.

W końcowych postanowieniach Sympozjum „Organizacja opieki nad dzieckiem kalekim jako zagadnienie służby zdrowia" zorganizowanej przez W. Degę w Poznaniu w dniach 21-23 IV 1966 r., w „Dezyderatach dla spraw nauczania i szkolenia dzieci i młodzieży kalekiej” opracowanych przez Komisję do opracowania dezyderatów dla spraw nauczania i szkolenia dzieci i młodzieży kalekiej zapisano m.in.: Dziecko kalekie - tak dtugo, jak jest to możliwe ze względów somatycznych $i$ intelektualnych powinno pozostawać $w$ swoim środowisku i uczęszczać do szkót normalnych. W szkołach normalnych $w$ wielkich zbiorowiskach ( miasta powyżej 100 tys. mieszkańców) w zależności od potrzeb ilościowych należy:

- tworzyć internaty dzienne (pótinternaty), a tam, gdzie takie istnieja dać bezwzględne pierwszeństwo $w$ przyjmowaniu do nich dzieciom i młodzieży kalekiej,

11 Z Majewska, Z. Anisimowicz, Organizacja nauki szkolnej u dzieci z kalectwem ruchowym wynikajacym z uszkodzenia ośrodkowego układu nerwowego, w: ibidem, s. 97.

${ }_{12}$ M. Staszewska, I. Liszkowska, A. Ogórkiewicz, Znaczenie kolonii letnich $w$ całokształcie rehabilitacji dzieci kalekich, w: ibidem, s. 131-132. 
- zabezpieczyć dzieciom ciężko poszkodowanym dowóz do szkót i internatów autokarami Prezydiów Rad Narodowych ${ }^{1313}$.

\section{Podsumowanie}

W. Dega otrzymał wiele odznaczeń państwowych oraz wiele wyróżnień państwowych, resortowych i regionalnych. Wyrazem uznania ze strony dzieci polskich było przyznanie profesorowi W. Dedze „Orderu Uśmiechu” nr 1.

Niestrudzona i wielostronna działalność profesora W. Degi znalazła odzwierciedlenie w piastowanych przez Niego funkcjach i godnościach. Był członkiem dziewięciu towarzystw naukowych krajowych i zagranicznych, między innymi: Amerykańskiej Akademii Chirurgów Ortopedycznych, Włoskiego Towarzystwa Ortopedii i Traumatologii oraz Akademii Chirurgów Francuskich w Paryżu. Był członkiem honorowym 4 towarzystw naukowych krajowych i 16 zagranicznych.

Wiktor Dega zmarł w dniu 16 lutego 1995 r. w wieku 98 lat.

\section{Bibliografia}

Dega W., Zapiski do autobiografii. Moja droga życiowa do wiedzy i zawodu, w: Wiktor Degaznany i nieznany, red. I. Stasiewicz - Jasiukowa, Poznań 2000.

Dega W., Kierunki rozwoju organizacji rehabilitacji dziecka z kalectwem narzadu ruchu, w: Organizacja opieki nad dzieckiem kalekim jako zagadnienie stużby zdrowia. Materiały z Sympozjum, red. W. Dega, Poznań 1966.

Dega W., Projekt organizacji lecznictwa ortopedycznego i opieki nad kalekami, Warszawa 1948.

Dezyderaty dla spraw nauczania i szkolenia dzieci i młodzieży kalekiej, „Komisja do opracowania dezyderatów dla spraw nauczania i szkolenia dzieci i młodzieży kalekiej”, przewodniczący Zbigniew Krynicki, w: Organizacja opieki nad dzieckiem kalekim jako zagadnienie stużby zdrowia. Materiały z Sympozjum, red. W. Dega, Poznań 1966.

Majewska Z., Anisimowicz Z., Organizacja nauki szkolnej u dzieci z kalectwem ruchowym wynikajacym z uszkodzenia ośrodkowego układu nerwowego, w: Organizacja opieki nad dzieckiem kalekim jako zagadnienie stużby zdrowia. Materiały z Sympozjum, red. W. Dega, Poznań 1966.

Poradowski R., Wiktor Dega - w kręgu Mistrza - szkic do portretu, Łódź 2001.

Staszewska M., Liszkowska I., Ogórkiewicz A., Znaczenie kolonii letnich w całoksztatcie rehabilitacji dzieci kalekich, w: Organizacja opieki nad dzieckiem kalekim jako zagadnienie stużby zdrowia. Materiały z Sympozjum, red. W. Dega, Poznań 1966.

13 Dezyderaty dla spraw nauczania i szkolenia dzieci i młodzieży kalekiej, „Komisja do opracowania dezyderatów dla spraw nauczania i szkolenia dzieci i młodzieży kalekiej”, przewodniczący Zbigniew Krynicki, w: ibidem, s. 146. 